\title{
Learning Strategy Approaches: Are There Differences Among Various Field Of Studies?
}

\author{
Asina Christina Rosito \\ Faculty of Psychology, Universitas HKBP Nommensen, Indonesia \\ asina.christina@uhn.ac.id
}

\begin{abstract}
Recently, the use of technology in learning has become more intensive. Students get access to different knowledge and skills quickly, using mobile phones, laptops, or tablets that connected to the internet. They can learn or read everywhere at any time. It seems that by using digital technologies, students can improve their ability to process information in meaningful way and to get more cognitively involved in their study. However, studies in recent years on students in several Asian countries showed the opposite, that in general students tend to process information in a surface way. This had become a trigger for us to conduct preliminary research to obtain a comprehensive view of undergraduate students' learning strategy approaches. In addition, this study aimed to explore whether there are differences in learning strategy approaches for different fields of studies. There were 221 undergraduate students of Universitas HKBP Nommensen (UHN), who involved in this study. They studied in various domain of studies such as economics $(n=50)$, psychology ( $\mathrm{n}=103)$, and agriculture (68). The instrument used was an adaptation version of ASSIST (Approaches and Study Skills Inventory for Students) that can identify the main learning strategy approach used by students. In general, there were no various significance differences among domains of study. However, few significance results were found. Psychology students used deep approach more intensively than agriculture students. In similar way, economics students used deep strategy approach more often than agriculture students. Some implications and further research suggestion were discussed.
\end{abstract}

Keywords: deep approach, surface approach, strategic approach, field of study.

\section{Introduction}

Higher education, specifically undergraduate programs, are required to produce graduates who mastering the theoretical concepts in a particular field of knowledge, and being able to solve problems. In addition, graduates are required to use technology in addition to their expertise knowledge for making effective adjustment 
and creative problem solving. Furthermore, graduates are expected to be able in making strategic decisions based on the analysis of information and data (Law of The Republic of Indonesia number, 12, year 2012).

Based on these objectives, the tertiary institution, through study programs within it, designs the curriculum in particular way to emerge graduates who able to meet these objectives and to answer needs of the wider community. Graduates are not expected to master knowledge merely in line to the science they had already learned, but also to have other supported competencies and good attitudes that might give positive impact both for their work of life and society.

However, it is often to be happened, that people's expectations of university graduates are not met. We make an interview with one human resource manager in one financial service company. Some complaints related to the quality of fresh graduates are identified, especially for the management trainee positions. Based on his years' experience in employee recruitment at the company, there are several qualities that he believes are not fulfilled in young scholars in recent years since they are lack of problem solving skills, low in stress resistance, and lack of working persistence.

The experience of researcher as lecturer in Universitas of HKBP Nommensen also supports this conclusion, in which students tend to complain when they are given a slightly more difficult assignment, to make negotiation for extending the due date of assignment that already instructed several weeks before, to give some outside reasons regarding to their fail in studying. When doing paper assignment, they tend to rely on information in internet rather than textbooks, not comparing information on the internet with those in books. Also, there are still some students that copy paste theirs' friend assignment.

These information could be an important feedback that need to be considered for faculty staffs in tertiary institutions. With the rapid development in technology and digitalization, where human civilization is currently entering the Industrial Revolution 4.0 period, students in higher education especially, need to improve the curiosity of data literacy, technology literacy, and human literacy, so that they can adapt to technological developments in the present time and future. In other words, students need to develop an attitude of a lifelong learner. The concept of lifelong learner is becoming a person who wants to pursue knowledge and learn new competencies throughout his life.

Learning to learn is one of the key competencies in lifelong learning processes (Mesaros, Mesarosova \& Mesarosova, 2012). Learning to learn is defined as the ability to pursue and persevere in learning, the ability to manage learning, through effective management of time and information, both individually and in groups (European Commission, 2007). A psychological concept related to learning to learn is learning strategy approach. Learning strategy approach is the tendency to accept and to process information gathered, as well as to improve learning through various and meaningful learning strategies. So, this concept is not directly related to intellectual ability, but more closely related to the strength of individual's willingness in undergoing learning processes and in selection of effective strategies used in 
mastering subject matter (Santrock, 2009). The initiators of learning strategy approach are Marton and Saljo (1976) who proposed two types approaches, namely deep approach and surface approach. Students with deep approach tend to show personal interest in learning, to look for the meaning behind the topic learned by trying to associate one idea to another, by connecting the course material to prior knowledge, looking for relevant evidence before make a conclusion. They likes new ideas and monitor their own understanding as well as find meaning from the things they learn. Students with a surface approach tend to use the memorization strategy in learning, focus on minimal requirements of tasks as described in the syllabus. They tend to be driven by fear of failure.

Biggs (1987) added one more approach, namely strategic approach. Students with this approach are able to manage time and learning environment effectively, being alert while working with various types of the assessment and monitor their own learning. They tend to have high intention of achieving good grades since they are driven by need of achievement.

Studies on undergraduate students' learning approaches has been done several times. A study by Booth, Luckett, \& Maldenovic (1999) at two universities in Australia showed that accounting students tend to use surface approach rather than deep approach. In addition, they also found that surface approach is negatively correlated to academic achievement, but there was no correlation between deep approach and academic achievement. The same result was found in Davidson's (2002) study of students in Canada, where accounting department students tended to apply surface approach.

A study by Byrne, Flood \& Willis (2009) indicated that accounting students in Ireland mostly adopt strategic approach compare to deep and surface approach. Another findings proposed that students majoring in biology at one of the universities in Australia tend to be surface learners (Watters \& Watters, 2007). Zeegers (2001) found the similar results where science students tend to use surface learning strategies in learning. A study by Nelson Laird, Shoup, Kuh, \& Schwarz (2008) that examined the effect of scientific disciplines on the deep approach of more than 80,000 final year students at more than 500 universities in the United States found that students from various discipline use deep approach to learning, but the most interesting finding is that students in soft fields (e.g. psychology) tend to be higher using the deep approach than students in hard fields (e.g. physics). A study by Byrne, Finlayson, Flood, Lyons, \& Willis (2010) of accounting and science students at one of Ireland's universities showed that accounting students tend to use a strategic approach rather than deep and surface approach, while science students do not show certain preferences. When accounting students are compared to science students, science students are significantly higher in using the deep approach than accounting students. On the other hand, accounting students are significantly higher in using strategic approach.

Studies of Indonesians undergraduate students' learning approaches are very few, especially in exploring the differences between fields of studies. Meanwhile, understanding of students' preferences in learning strategy are important to be considered in order to help them improve their quality of learning which is in turn 
will give impact on their academic performance. In addition, learning approach is not individuals' internal characteristic, but rather individuals' responses to the learning environment situation that they faces. Hence, learning approach could be improved. When students choose a particular field of study, which is unique in content, they are dealing with specific teaching context involving curriculum, type of assessments, forms of lecturer feedback, and many other factors related to their study process. Those contextual factors could affect the learning approach applied by students. Since each field of study is specific in content and object of study, it leads to specific way of thinking that may lead to specific learning approach. So, it may also be assumed that there would be differences in students' approach in learning among different field of studies.

This research explores students' preferences in learning strategies especially students in psychology, economics, and agriculture. In addition, this study examined whether there are differences in their use of learning approach.

In accordance to the Law of the Republic of Indonesia number 12 year 2012 about Higher Education, there are several clusters of science. First, the cluster of religious sciences. Religious science is a body of knowledge that examines the beliefs of divinity or deity of religion. Secondly, cluster of humanities that explores human values and human thought, such as philosophy and language science. Third, cluster of social science that focuses on human relationships and various social phenomena, such as sociology, psychology, culture and economic science. Fourth, cluster of natural science is specific science that studies and explores the universe other than humans, such as biology and physics. Fifth, cluster of formal science which studies and integrates theoretical formal systems, such as computer science and mathematics. Sixth, cluster of applied science that studies and examines the application of science for human life including agriculture, engineering and health.

Psychology as one of the areas of science in the social sciences focuses on human behavior and the mental processes, as its main study objects. Various concepts, principles, theories, and research in psychology provides description of human behavior, explanation of behavior and prediction of human behavior, in all aspects of life. Therefore, psychology students are likely to connect psychological concepts, ideas, principles and theories with themselves, as humans, and with others. Advanced psychological studies conduct in-depth analysis of human behavior, and develop a range of psychological services and strategies in order to improve the quality of humans' life.

Economics is also one part of the social science cluster. Economics is the science of the principles of production, distribution, and use of goods and wealth, money, energy, time, and others resources in human life. This study's orientation to apply economic concepts, principles and theories for the efficiency and effectiveness in the use of human resources in order to improve their life. Hence, economics' students might accustomed to apply economics principles in solving economics problems.

The agricultural study is one of applied sciences, which focuses on efforts to manage biological resources, in this case plants, in order to produce good quality of food, to 
fulfill the needs of raw materials for industries, and source of energy. Thus, students in this department are trained to find ways and solutions related to soil and plants.

Based on previous analysis that describe the uniqueness of each field of study, several questions emerged: which type of learning approach that tend to be applied by students with different field of study? Are there significant differences in the use of learning approaches by students with different field of study?

\section{Significance of the study}

This study gives empirical evidence related to how students' preferences in their approach of learning. The results of this study will give some insights concerning to implications of teaching and learning especially in three major of studies that included in this study. These findings will beneficial for lecturers as well as faculty administrators since they describe the preferences of learning approach adopt by students.

To students, findings of this study give description of theirs' tendency of learning approach while studying. In addition, the results can help them to reflect how they can improve their learning quality.

To future research related to learning strategy approach in higher education, the output of this study could serve as starting point for more advance study in identifying some contextual or individual's factors that related to students preferences in learning. In addition, some insights might emerge based on this study's findings that related to examine various effect of specific learning strategy approach in students' quality of learning as well as academic performance.

\section{Scope and Limitation of the study}

This study aims to obtain an overview of the use of learning strategy approach in undergraduate students of Universitas of HKBP Nommensen, especially in three field of studies, psychology, economics and agriculture. Furthermore, investigates whether there are differences in the preferences of learning strategy approaches among different major of students. Considering that the respondents of this study were students from a particular university, with relatively homogeneous in cultural and religious backgrounds, the results of this study could not be generalized for students from other universities.

\section{Setting of the study}

This study was conducted in Universitas HKBP Nommensen (UHN), one of prestigious private university in Medan, North Sumatera, Indonesia, during the first semester of academic year 2018-2019.

Universitas HKBP Nommensen was established on 7 October 1954. At the time of its opening, the University had three (3) faculties, namely the Faculty of Law, Faculty of Economics and Faculty of Theologies, then followed by the opening of the Faculty of Social and Political Sciences in 1961, Faculty of Teaching and Education in 1962, the Faculty of Engineering in 1975, the Faculty of Animal Husbandry in 1976, the 
Faculty of Agriculture in 1984, Faculty of Language and Art in 1987, Faculty of Psychology in 2001, Faculty of Medical in 2009, and Post-graduate Program in 2003. At present, the University is consisting of eleven (11) faculties and twenty five (25) major of studies for undergraduate degrees. There are three (3) master degree conducted nowadays in UHN.

\section{RESEARCH DESIGN AND METHODOLOGY}

This study is a quantitative approach research in which use empirical data to gather information related to the variables examined. The primary data is gathered using research instrument that measure the learning strategy approach used by participants. Since the research questions argued about whether there are learning approach differences in participants form different major of studies, then the inferential statistics will be used to test the hypothesis.

\section{Respondents of the study}

Respondents in this study were active students at Universitas HKBP Nommensen in 2018/2019 academic year, in total of 221 respondents (males $=78$, females $=143$ ). Based on their field of study, there are 103 psychology students, 50 economics students, and 68 agriculture students.

Psychology and economics represents the field of human sciences, while agriculture represents the field of applied science.

\section{Research instrument}

The adaptation version of Approaches and Study Skills Inventory for Students (ASSIST) was employed to assess the learning strategy approach. It was developed by Entwistle \& Tait (1997) in order to assess the relative strengths of students' learning approach in three dimensions: deep, surface, and strategic approach. It is a 52 items scale that divided into three approach: deep approach (16 item), strategic approach (20 item), and surface approach (16 item). Participants were asked to choose between five alternatives, strongly agree, agree, disagree, and strongly disagree. The score of this scale will be categorized into three different approaches, later it would be transformed into z score, in which the participants can be classified into deep approach learner, strategic approach learner, or a surface approach learner.

\section{Data Gathering Procedure}

Data collection was conducted by distributing questionnaire of ASSIST to respondents. Respondents were asked beforehand about their willingness to involve in this study. After the prospective respondents agreed to involve in the study, researcher gave a questionnaire and guided them in filling out of the questionnaire. After the questionnaire filled properly, researcher thanked them and gave a souvenir in return for their voluntary involvement in this study. 


\section{Statistical Analysis}

The purpose of this study is to find out whether there are differences in the learning strategy approach used by students from different field of study. Therefore, one way analysis of variance was conducted to test the hypothesis. Descriptive statistics also used such as mean, standard deviation, frequency and percentage in several aspect of data that collected

\section{FINDINGS AND CONCLUSIONS}

Based on the descriptive statistics, the socio-demographic profiles of the respondents could be summarized (see Table 1). It can be concluded that the age of respondents varied between 18 years to 33 years of old, with respondents in age 20 are the most involved in this study. In addition, from the cultural background, most of respondents $(89.1 \%)$ are Batakness, one of tribes in North Sumatera.

Table 2 give a glance of statistic description variables examined. Strategic approach has the highest mean (73.43) and standard deviation (7.49) followed by deep approach (M= 59.77, SD 6.08) and surface approach (M= 55.39, SD 6.10).

Based on the analysis of data gathered using the ASSIST, students preferences of learning approach could be summarized (see Table 3). Almost half of respondents (43\%) applied surface approach, followed by 32.6 of them adopt strategic approach. Furthermore, only $24.4 \%$ of respondents use deep approach.

Table 1

Socio-demographic profiles of respondents

\begin{tabular}{cll}
\hline & Frequency & Percentage \\
\hline Gender & & \\
\hline Males & 78 & 35.3 \\
Females & 143 & 64.7 \\
\hline Ages & & \\
\hline 18 & 10 & 4.5 \\
19 & 45 & 20.4 \\
20 & 73 & 33.0 \\
21 & 60 & 27.1 \\
22 & 26 & 11.8 \\
23 & 6 & 2.7 \\
33 & 1 & .5 \\
\hline Tribes & & \\
\hline Batakness & 197 & 89.1 \\
Nias & 18 & 8.1 \\
Ambon & 1 & .5 \\
Melayu & 1 & .5 \\
Chinese & 1 & .5 \\
Others & 3 & 1.3 \\
\hline
\end{tabular}


Table 2

Descriptive statistics

\begin{tabular}{lll}
\hline $\begin{array}{l}\text { Learning strategy } \\
\text { approach }\end{array}$ & Mean & $\begin{array}{l}\text { Standard } \\
\text { Deviation }\end{array}$ \\
\hline Deep approach & 59,77 & 6,08 \\
$\begin{array}{l}\text { Strategic } \\
\text { approach }\end{array}$ & 73,43 & 7,49 \\
$\begin{array}{l}\text { Surface approach } \\
\text { Descriptive }\end{array}$ & 55,39 & 6,10 \\
\hline
\end{tabular}

Table 3

Categorization of learning strategy approach

\begin{tabular}{lll}
\hline $\begin{array}{l}\text { Learning strategy } \\
\text { approach }\end{array}$ & $\mathrm{N}$ & Percentage \\
\hline Deep approach & 54 & 24.4 \\
Strategic approach & 72 & 32.6 \\
Surface approach & 95 & 43.0 \\
\hline Total & 221 & 100 \\
\hline
\end{tabular}

Table 4

Categorization of learning strategy approach based on gender

\begin{tabular}{llll}
\hline $\begin{array}{l}\text { Learning strategy } \\
\text { approach }\end{array}$ & Male & Female & $\mathrm{N}$ \\
\hline $\begin{array}{l}\text { Deep approach } \\
\text { Strategic } \\
\text { approach }\end{array}$ & 18 & 36 & 54 \\
$\begin{array}{l}\text { Surface approach } \\
\text { Total }\end{array}$ & 36 & 48 & 72 \\
\hline
\end{tabular}

Based on data described in Table 4, it is shown that there are 18 male students apply deep approach, while 36 female students adopt this approach. Regarding to strategic approach, there are 24 male students who apply strategic approach and 48 female students who prefer to us this approach. With regard to surface approach, there are 36 male students who adopt this approach, while 59 female students tend to use this approach.

In order to test, whether there are differences between male and female students in using those three learning strategy approach, an independent t-test was conducted. The results show that in deep approach, there is no significant differences between male and female students $(\mathrm{t}=.162, \mathrm{p}=.87)$. Also, there is no significant differences between them in strategic approach $(\mathrm{t}=.109, \mathrm{p}=.90)$ as well as in surface approach $(\mathrm{t}=-.35, \mathrm{p}=.70)$. In conclusion, there is no differences between male and female students in learning strategy approach they adopt.

Table 5 describes the descriptive statistics of participants with different year of study in their using of learning strategy approach. In order to explore, whether there are 
differences in learning strategy used between participants in terms of their year of study, an analysis of variance was conducted. The results shows that there is a difference in the use of a deep approach in terms of year of study $(\mathrm{F}(2,218)=6.43$, $\mathrm{p}$ $=.002)$. First, the mean score sophomore students was significantly higher $(\mathrm{M}=$ $61.74, \mathrm{SD}=5.63)$ compared to junior students $(\mathrm{M}=58.87, \mathrm{SD}=6.41)$ in the use of a deep approach to the learning process. Second, students of sophomore year were significantly higher $(\mathrm{M}=61.74, \mathrm{SD}=5.63)$ compared to students of the senior year $(\mathrm{M}=58.46, \mathrm{SD}=5.32)$ in using the deep approach to the learning process. In other side, there was no differences in using deep approach between junior students $(\mathrm{M}=$ $58.87, \mathrm{SD}=6.41)$ and senior students $(\mathrm{M}=58.46, \mathrm{SD}=5.32)$.

Tabel 5

Descriptive statistics of learning approach strategy for year of study

\begin{tabular}{lllllll}
\hline \multirow{2}{*}{$\begin{array}{l}\text { Year } \\
\text { study }\end{array}$} & $\begin{array}{l}\text { Deep } \\
\text { approach }\end{array}$ & \multicolumn{2}{c}{$\begin{array}{l}\text { Strategic } \\
\text { approach }\end{array}$} & \multicolumn{2}{l}{$\begin{array}{l}\text { Surface } \\
\text { approach }\end{array}$} \\
\cline { 2 - 7 } & Mean & SD & Mean & SD & Mean & SD \\
\cline { 2 - 7 } Sophomore & 61.74 & 5.63 & 75.66 & 6.37 & 55.64 & 5.65 \\
Junior & 58.87 & 6.41 & 72.33 & 7.77 & 55.41 & 6.34 \\
Senior & 58.46 & 5.32 & 72.09 & 7.87 & 54.91 & 6.39 \\
\hline
\end{tabular}

\section{Tabel 6}

Categorization of learning approach strategy for different field of study

\begin{tabular}{llll}
\hline Major & $\begin{array}{l}\text { Deep } \\
\text { approach }\end{array}$ & $\begin{array}{l}\text { Strategic } \\
\text { approach }\end{array}$ & $\begin{array}{l}\text { Surface } \\
\text { approach }\end{array}$ \\
\hline & $\mathrm{N}(\%)$ & $\mathrm{N}(\%)$ & $\mathrm{N}(\%)$ \\
\cline { 2 - 4 } Psychology & $33(32 \%)$ & $34(33 \%)$ & $36(35 \%)$ \\
Economics & $10(20 \%)$ & $18(36 \%)$ & $22(44 \%)$ \\
Agriculture & $11(16.2 \%)$ & $20(29.4 \%)$ & $37(54.5 \%)$ \\
\hline
\end{tabular}

Table 7

Descriptive statistics of learning approach strategy for different discipline

\begin{tabular}{lllllll}
\hline Major & \multicolumn{2}{l}{$\begin{array}{l}\text { Deep } \\
\text { approach }\end{array}$} & \multicolumn{2}{c}{$\begin{array}{l}\text { Strategic } \\
\text { approach }\end{array}$} & \multicolumn{3}{c}{$\begin{array}{l}\text { Surface } \\
\text { approach }\end{array}$} \\
\cline { 2 - 7 } & Mean & SD & Mean & SD & Mean & SD \\
\cline { 2 - 7 } Psychology & 60.75 & 6.03 & 73.52 & 6.56 & 54.42 & 6.05 \\
Economic & 61.10 & 4.90 & 76.22 & 8.30 & 56.72 & 4.89 \\
Agriculture & 57.31 & 6.29 & 71.22 & 7.58 & 55.88 & 6.77 \\
\hline
\end{tabular}

Another findings in the ANOVA is there is a difference in the use of a strategic approach in terms of the year of study $(\mathrm{F}(2,218)=5.36, \mathrm{p}=.005)$ where students of sophomore year are significantly higher $(\mathrm{M}=75.66, \mathrm{SD}=6.37)$ compared to students of junior year $(\mathrm{M}=72.33, \mathrm{SD}=7.77)$ in using the strategic approach in the learning 
process. With regard to the use of surface approach, there is no difference in the use of a surface approach in terms of year of study $(\mathrm{F}(2,218)=2.75, \mathrm{p}=.066)$.

Table 6 shows the distribution of learning approach preferences of participants with different major of studies. It can be seen that $35 \%$ of psychology students used surface approach, followed by $33 \%$ applied strategic approach, and $32 \%$ employed deep approach. It seems that psychology students do not have major tendencies in using these learning approach. For economic students, it is almost half of them (44\%) used surface approach and $36 \%$ used strategic approach. There is only $20 \%$ employ deep approach. In addition, for agriculture students, more than half of them (54.5\%) used surface approach and $29.4 \%$ apply strategic approach. It can be concluded that participants from three major of studies, are more likely to use surface approach.

The results of the ANOVA for each learning strategy approach in terms of field of study, found several things. First, there are differences in using deep approach among psychology, economics, and agriculture students $(\mathrm{F}(2,218)=8.65, \mathrm{p}=.000)$. Psychology students was significantly higher in using deep approach $(\mathrm{M}=60.75$, SD $=6.03)$ compared to agriculture students $(\mathrm{M}=57.31, \mathrm{SD}=6.29)$. Furthermore, economics students were significantly higher $(M=61.10, S D=4.90)$ compared to agriculture students $(\mathrm{M}=57.31, \mathrm{SD}=6.29)$ in using deep approach. However, there was no difference in the deep approach between psychology students $(M=60.75, \mathrm{SD}$ $=6.03)$ and economics students $(\mathrm{M}=61.10, \mathrm{SD}=4.90)$.

These results are consistent with the results of research conducted by Senemoglu (2011) of Turkish students from several different majors, where students who study humanities are significantly higher in using the deep approach than preschool and math-science students. This research is also in line with findings by Smith \& Miller (2005) which show that fields of science such as humanities are more focused on interpreting ideas, building appropriate arguments and conducting critical and reflective evaluations of various subject matter provided, when compared to 'hardpure' (like physics, and chemistry).

Second, based on the ANOVA for learning strategies used by three majors of studies, it was found that there are differences in the use of strategic approach $(\mathrm{F}(2,218)=$ $6.77, \mathrm{p}=.001)$ where students of the faculty of economics are significantly higher ( $\mathrm{M}$ $=61.10, \mathrm{SD}=4.90)$ compared to students of the faculty of agriculture $(\mathrm{M}=57.31$, $\mathrm{SD}=6.29$ ) in using the strategic approach in the learning process. This finding support previous study Byrne, et.al (2010) that found accounting students, as part of economics science) are significantly higher in using strategic approach than science students.

Third, there was no difference in the use of a surface approach in terms of different field of study $(\mathrm{F}(2,218)=2.75, \mathrm{p}=.066)$.

As the main findings in this study show that both psychology students and economics students having high preference in using deep approach than agriculture students, some explanations might arise. Even though they distinguish each other, but there are some similarities between. First, both of them are directly interact with human as the purpose of the study. In psychology, students are accustomed to observe and make reflection related to human behavior and mental processes. They are trained to 
perceive human as unique and to explain and describe human in context based on several major perspective, namely psychoanalytical, behavioral, cognitive, and humanistic. Economics students, especially in management study, also learn about how to manage human resources in context of organizations. Hence, they also study some basic principal of people management in understanding and improving their performance. They are also learn about human behavior in context of economics, such as consumer behavior.

Second, they are also shared the same methods in research, for example in using descriptive study and correlational study with human in different context. It is indicated both of field of study have similar frame of thinking in examining and exploring of human behavior in special context.

Students in agriculture are having low tendency to learn in deep approach if compared to both psychology and economics students. It can be explained in the term of the main focus of agriculture study, which is the management of biological resource such as plants, which is related to studies about weather, soils, seeds, plan pests, and other factors that affect the plants productions.

Finally, since almost half of the participants adopt surface approach, some explanations can summarized. Since all of them attend the same university, they are given the same major learning environment, in terms of they are using and sharing the major facilities, such as university library, lecture rooms, sport facilities, as well as health facilities. Most of faculty in this university, conduct the lectures in big size of class, around 40-80 persons, vary to one study to another. These amount of students may not effective in teaching some specific skills, and hinder the opportunity to interact intensively between lecturer and students. In addition, the assessment method used are typically paper pencil tests, with essay or multiple choice forms, that conducted at least two times, mid and end of semester. The tendency to use these type of assessment might impact the preference of surface approach.

\section{RECOMMENDATIONS}

First, for the instructors and faculty administrators at Universitas HKBP Nommensen, results of this study could be used as empirical data in obtaining an overview of the students' learning approach tendencies, specifically in faculty of psychology, economics, and agriculture. The findings could serve as baseline data in re-design the teaching and assessment methods, since these contributes to which learning approach tend to be adopted by students. Even though this study did not include the academic performance, previous studies confirmed that both deep and strategic approach have impact on academic achievement, so instructors might considering to explore how they can improve students learning skills and strategies in terms of deep and strategic approach.

For example, in order to improve students' ability to make elaboration, analysis, then teaching techniques need to emphasize the learning process based on students such as doing project-based learning, problem based learning and collaborative learning. In addition, assessment techniques that are used also affect their learning patterns, where assessment techniques which are oriented to conducting analysis and synthesis will 
increase the ability of problem solving and decision making. Examples of types of assessments include case studies.

Second, for students, who in this study in general have a preference to adopt surface approach, to make some reflection about how they learn along this time. They need to identify the effectiveness of their learning strategy used this far. They can change their perception about learning and strategies in learning. Students could consult this matter with the instructor or other supervisors in faculty.

Third, further research can explore the differences in learning approaches for other field of study such as the religious studies, humanities, natural sciences and formal sciences. By considering that this study was conducted at a private university in Medan, where the majority of students come from certain cultural backgrounds, Batakness, so that it tends to be homogeneous, the results of this study cannot be generalized to populations outside the University. Future studies can consider the problem of the diversity of ethnic backgrounds of the study population, so that research on the topic of this learning approach is analyzed and utilized on a broader scale.

\section{REFERENCES}

Beaten, M., Kyndt, E., Struyven, K., \& Dochy, F. (2010). Review: Using studentcentred learning environments to stimulate deep approaches to learning: Factors encouraging or discouraging their effectiveness. Educational Researh Review, 5, 243260.

Bigss, J. B. (1987). Student approaches to learning and studying. Australia Council for Education Research, Howthorn, VIC.

Biggs, J.B., \& Moore, P.J. (1993). The process of learning, 3rd edition. Prentice-Hall. Australia

Byrne, M., Finlayson, O., Flood, B., Lyons, O., \& Willis, P. (2010). A comparison of the learning approaches of accounting and science students at an Irish university. Journal of Further and Higher Education, 34, 3, 369-383.

Booth, P., Luckett, P., \& Maldenovic, R. (1999). The quality of learning in accounting education: The impact of approaches to learning on academic performance. Accounting Education: An International Journal 8 (4), pp. 277-300

Byrne, M., Flood, B., \& Willis, P. (2009). An inter-institutional exploration of the learning approaches of students studying accounting. International Journal of Teaching and Learning in Higher Education, 20 (2), pp. 155-167.

Chamorro-Premuzic, T., \& Furnham, A. (2008). Personality, intelligence and approaches to learning as predictors of academic performance. Personality and Individual Differences, 44, 1596-1603. 
Davidson, R. (2002). Relationship of study approach and exam performance. Journal of Accounting Education, 20, pp. 29-44.

Entwistle, N. J., and Tait, H. (1996). Approaches and Study Skills Inventory for Students. Centre for Research on Learning and Instruction, University of Edinburgh, Edinburgh

European Commision (2007). Key Competences for Lifelong Learning. European Reference Framework. Luxembourg: Office for Official Publications of the European Communities.

Fung, L. Y. (2010). A study on the learning approaches of Malaysian students in relation to English language aquisition. Am Journal Science Ind Research 9, 5-11.

Gijbels, D., van de Watering, G., \& Dochy, F. (2005). Integrating assessment tasks in a problem-based learning environment. Assessment and Evaluation in Higher Education, 30 (1), 73-86.

Goh, P.S.C, Wong, K.T., \& Osman, R. (2012). Student-teachers' approaches to learning, acedemic performance and teaching efficacy. Malaysian Journal of Learning and Instruction, 9, 31-46.

Kek, Y.C., Darmawan, I. G. N., \& Chen, Y. S. (2007). Family, learning environments, learning approaches, and student outcomes in a Malaysian private university. International Education Journal, 8 (2): 318-336.

Komarraju, M., Karau, S.J., Schmeck, R. R., \& Avdic, A. (2011). The Big five personality traits, learning styles, and academic achievement. Personality and Individual differences. Vol 51, 472-477.

Law of The Republic of Indonesia number, 12, year 2012

Leung, M. Y, Li, J. Y., Fang, Z, Lu, X. H. (2006). Learning approaches of construction engineering students: a comparative study between Hong Kong and mainland China. Journal Education Built Environment, 1 (1), 112-131.

Marton, F., \& Saljo, R. (1976). On qualitative differences in learning I-Outcome and process. Br J Educational Psychology, 46, 4-11

Mesaros, P. , Mesarosova, M., \& Mesarosova, L. (2012). Learning to learn competency, metacognitive learning strategies and academic self-concept of university students. International Journal of Arts\&Sciences, 5 (2), 489-497. 
Nelson Laird, T., Shoup, R., Kuh, G., Schwarz, M. (2008). The effects of discipline on deep approaches to student learning and college outcomes. Research in Higher Education, 49 (6), 469-494.

Santrock, J. W.(2009). Psikologi Pendidikan, edisi 3, buku 2. Jakarta: Penerbit Salemba Humanika

Sedaghat, M., Abedin, A., Hejazi, E. \& Hassanabadic, H. (2011). Motivation, cognitive engagement, and academic achievement. Procedia Social and Behavioral Sciences 15, 2406-2410

Senemoglu, H. (2010). College of Education Students' Approaches to Learning and Study Skills. Education and Science, 36 (160)

Smith, N. S., \& Miller, R. J. (2005). Learning approaches: examination type, discipline of study, and gender. Educational Psychology, 25 (1), 43-53.

Watters, D., \& Watters, J. (2007). Approaches to learning by students in biological science: implications for teaching. International Journal of Science Education, 29 (1), $19-43$.

Wigfield, A., \& Eccless, J. S. (2000). Expectancy-value theory of achievement motivation. Contemporary Educational Psychology, 25, 68-81.

Zeegers, P. (2001). Approaches to learning science: A longitudinal study. British Journal of Educational Psychology, 71 (1), 115-132.

Ziguras, C. (2001). Educational Technology in transnational higher education in South East Asia: the cultural politics of flexible learning. Educational Technology Soc, $4(4$ 